\title{
TINGKAT INOVASI SEBAGAI STRATEGI PENGEMBANGAN PRODUK USAHA KECIL MENENGAH DI DESA KEBONHARJO
}

\author{
Heri Nurranto $^{1)}$, Fajar Kurniadi ${ }^{2)}$ Askardiya Mirza Gayatri ${ }^{3)}$ \\ ${ }^{1,2,3}$ Program Studi Pendidikan Ekonomi, \\ Fakultas Ilmu Pendidikan dan Pengetahuan Sosial, Universitas Indraprasta PGRI \\ E-mail : heri.nurranto@gmail.com \\ Diterima: 11 Desember; Disetujui: 28 Maret; dipublikasikan: 28 April 2019
}

\begin{abstract}
This study aims to determine the level of product innovation and the obstacles faced by small businesses of palm sugar producers and etawa goat milk farmers in Kebonharjo Village, Samigaluh District, Kulonprogo Regency. The method used in this study is a qualitative research method and a sequential explanatory descriptive approach. The sample of the study was 75 people consisting of 54 palm sugar producers and 21 etawa goat milk breeders in Kebonharjo Village, Samigaluh District, Kulonprogo Regency. The analytical approach uses index numbers, the result is a product innovation index of 31.80 palm sugar producers and etawa goat milk farmers 13.14. The constraints faced by small-scale business actors are not focused on running a business, the way of production has passed both ways and development, geographical conditions, motivation for business development is relatively lacking, production capacity depends on the availability of natural resources, capital, distribution and marketing access, patterns of substantive economic activities and comparative advantages that make people feel comfortable.
\end{abstract}

Keywords: Innovation, Product Development, SMEs

\begin{abstract}
ABSTRAK
Penelitian ini bertujuan mengetahui tingkat inovasi produk dan hambatan-hambatan yang dihadapi pada usaha kecil pengrajin gula aren dan peternak susu kambing etawa di Desa Kebonharjo, Kecamatan Samigaluh, Kabupaten Kulonprogo. Metode yang digunakan dalam penelitian ini adalah metode penelitian kualitatif dan pendekatan deskriptif sequential explanatory. Sampel penelitian sebanyak 75 orang yang terdiri 54 orang pengrajin gula aren dan 21 orang peternak susu kambing etawa di Desa Kebonharjo, Kecamatan Samigaluh, Kabupaten Kulonprogo. Pendekatan analisis menggunakan angka indeks, hasilnya adalah indeks inovasi produk pada pengrajin gula aren 31,80 dan peternak susu kambing etawa 13,14. Kendala yang dihadapi oleh para pelaku usaha kecil tersebut adalah tidak fokus dalam menjalankan usaha, cara produksi turun temurun baik cara maupun pengembangannya, kondisi geografis, motivasi pengembangan usaha yang relatif kurang, kapasitas produksi bergantung dari ketersediaan sumber daya alami, permodalan, akses distribusi dan pemasaran, pola kegiatan ekonomi substantif serta keunggulan komparatif yang membuat masyarakat merasa nyaman.
\end{abstract}

Kata Kunci: Inovasi, Pengembangan Produk, UKM 


\section{sosio e-kons}

Volume 11, No. 1, April 2019, pp. 1-15

e-ISSN: 2502-5449

p-ISSN: 2085-2266

DOI : 10.30998/sosioekons.v11i1.3068

\section{PENDAHULUAN}

Kegiatan usaha kecil dan menengah (UKM) di Indonesia diharapkan menjadi pilar dasar dalam meningkatkan pertumbuhan ekonomi di Indonesia. Kontribusi pelaku usaha kecil memiliki peran dalam membuka kesempatan kerja dan menambah pendapatan negara terutama pada sektor non migas. Peranan dalam ekonomi kreatif berbasis Usaha Kecil Menengah (UKM) yang semakin meningkat membutuhkan bentuk-bentuk inovasi, baik yang bersifat fisik maupun nonfisik.

Berdasarkan Undang-undang No. 20 tahun 2008 tentang UMKM, usaha kecil menengah adalah usaha ekonomi produktif yang berdiri sendiri yang dilakukan oleh orang perorangan atau badan usaha yang bukan merupakan anak perusahaan atau cabang perusahaan yang dimiliki, dikuasai atau menjadi bagian, baik langsung maupun tidak langsung dengan usaha kecil atau hasil penjualan tahunan sebagaimana diatur dalam undang-undang.

Kriteria usaha kecil menengah berdasarkan Undang-undang No. 20 tahun 2008 juga menguraikan kriteria usaha kecil menengah, yaitu, 1) kekayaan bersih lebih dari Rp. 500.000.000,- lima ratus juta rupiah) sampai dengan Rp. 10.000.000.000,- (sepuluh milyar rupiah) tidak termasuk tanah dan bangunan tempat usaha; 2) memiliki hasil penjualan tahunan lebih dari Rp. 2.500.000.000,- (dua milyar lima ratus juta rupiah) sampai dengan Rp. 50.000.000.000,- (lima puluh milyar rupiah). Lebih lanjut, undang-undang No. 20 tahun 2008 UMKM menyebutkan bahwa dalam menjalankan kegiatan pemberdayaan usahanya didasarkan oleh Pertama, asas kekeluargaan, yaitu asas yang melandasi upaya pemberdayaan UMKM sebagai bagian dari perekonomian nasional yang diselenggarakan berdasarkan atas dasar demokrasi ekonomi dengan prinsip kebersamaan, efisiensi berkeadilan, berkelanjutan, berwawasan lingkungan, kemandirian, keseimbangan, kemajuan dan kesatuan ekonomi nasional untuk kesejahteraan seluruh rakyat Indonesia. Kedua, asas demokrasi ekonomi, yaitu pemberdayaan UMKM diselenggarakan sebagai kesatuan dari pembangunan perekonomian nasional untuk mewujudkankemakmuran rakyat.Ketiga, asas kebersamaan, yaitu asas yang mendorong peran seluruh UMKM dan dunia usaha secara bersama-sama dalam kegiatannya untuk mewujudkan kesejahteraan rakyat. Keempat, asas efisiensi berkeadilan, yaitu asas yang mendasari pelaksanaan pemberdayaan UMKM dengan mengedepankan efisiensi berkeadilan dalam usaha untuk mewujudkan iklim usaha yang adil, kondusif dan berdaya saing. Kelima, asas berkelanjutan, yaitu asas yang secara terencana mengupayakan berjalannya proses pembangunan melalui pemberdayaan UMKM yang dilakukan secara berkesinambungan sehingga terbentuk perekonomian yang tanggung dan mandiri. Keenam, asas berwawasan lingkungan, yaitu asas pemberdayaan UMKM yang dilakukan dengan tetap memerhatikan dan mengutamakan perlindungan dan pemeliharaan lingkungan hidup. Ketujuh, asas kemandirian, yaitu asas pemberdayaan UMKM yang dilakukan dengan tetap menjaga dan mengedepankan potensi, kemampuan dan kemandirian UMKM. Kedelapan, asas keseimbangan kemajuan, yaitu asas pemberdayaan UMKM yang berupaya menjaga keseimbangan kemajuan ekonomi wilayah dalam kesatuan ekonomi nasional. Kesembilan, asas kesatuan ekonomi nasional, yaitu asas pemberdayaan UMKM yang merupakan bagian dari perimbangan kesatuan ekonomi nasional.

Selain asas-asas tersebut, pemberdayaan UMKM dalam Undang-undang No 20 tahun 2008 pada Pasal 4 menganut prinsip-prinsip penumbuhan kemandirian, kebersamaan dan kewirausahaan. Peran pemerintah dalam mengembangkan UMKM, seperti yang diuraikan 


\section{sosio e-kons}

Volume 11, No. 1, April 2019, pp. 1-15

e-ISSN: 2502-5449

p-ISSN: 2085-2266

DOI : 10.30998/sosioekons.v11i1.3068

dalam UU no 20 tahun 2008 Pasal 7 ayat (1), berisi : "Pemerintah dan Pemerintah Daerah menumbuhkan iklim usaha dengan menetapkan peraturan perundang-undangan dan kebijakan yang meliputi aspek : a)pendanaan, b) sarana dan prasarana, c) informasi usaha, d) kemitraan, e) perizinan usaha, f)kesempatan berusaha, g) promosi dagang, dan h) dukungan kelembagaan.

Levitt seperti yang dikutip oleh Zimmerer (Astamoen, 2008: 200), keinovasian adalah 'doing new things' (melakukan sesuatu yang baru). Drucker (2006:111) memberikan batasan definisi inovasi, pertama bahwa inovasi adalah fungsi spesifik dari kewirausahaan, baik dalam bisnis yang sudah ada, institusi pelayanan publik atau spekulasi individu dari dapur keluarga. Kedua bahwa inovasi adalah alat bagi pengusaha untuk menciptakan sumberdaya baru yang memproduksi kekayaan atau memberi peningkatan potensi sumber daya yang sudah ada untuk menciptakan kekayaan. Zimmerer dan Scarborough (2005: 40), inovasi adalah kemampuan untuk menerapkan solusi kreatif terhadap masalah dan peluang tersebut untuk meningkatkan atau untuk memperkaya kehidupan orang-orang. Jadi, inovasi dapat ditampilkan sebagai ilmu, dapat dipelajari dan dapat dipraktikkan.

Keberadaan inovasi berkaitan dengan kreativitas. Kreativitas diartikan sebagai kemampuan untuk mengembangkan gagasan-gagasan baru dan untuk menemukan cara-cara baru dalam melihat masalah dan peluang (Zimmerer dan Scarborough, 2005: 40). Dalam implementasi mengembangkan kreativitas, menurut Rusdiana (2014: 102) terdapat tiga tipe kreatif yang berbeda, yaitu 1) membuat atau menciptakan; 2) mengombinasikan atau menyintesiskan; dan 3) memodifikasi sesuatu yang sudah ada. Adapun manusia sebagai pelaku atau pelaksana inovasi maka manusia yang termasuk dalam kategori berpikir kreatif menurut Kao, Jhon (Rusdiana,20014: 105) adalah 1) melihat sesuatu dengan cara yang tidak biasa. 2) keingintahuan yang besar. 3) menerima dan menyesuaikan yang kelihatannya berlawanan. 4) percaya pada diri sendiri, 5) tekun, 6) dapat menerima perbedaan, 7) keterbukaan pada pengalaman, 8) independen dalam pertimbangan, pemikiran, dan tindakan dan 8) membutuhkan dan menerima otonomi.

Menurut Sofjan Assauri (2011: 1), suatu perusahaan dapat memiliki keunggulan bersaing bila berhasil merancang dan mengimplementasikan strategi penciptaan nilai atau value, penciptaan value dapat terjadi jika para pesaing tidak menggunakan atau melakukan strategi yang sama. Assauri juga menekankan bahwa keunggulan bersaing tersebut hanya dapat dipertahankan bila para pesaing yang ada sekarang maupun pesaing yang baru tidak meniru dan menggantikannya.

Menurut Basrowi (2014: 125), keunggulan bersaing adalah suatu manfaat yang ada ketika suatu perusahaan mempunyai dan menghasilkan suatu produk atau jasa yang dilihat dari pasar targetnya lebih baik dibandingkan dengan para kompetitor terdekat. Secara garis besarnya, strategi dalam keunggulan bersaing dapat diilustrasikan mulai dari mengenali peluang, mengatur fasil dari eksploitasi dan memilih strategi untuk menangkap peluang. Dari tahapan tersebut, untuk mencapai keunggulan bersaing menurut Leonardus (Basrowi, 2014: 125), seorang pelaku usaha harus mampu meningkatkan daya inovasi, kreatif, dan produktivitas dengan teknik-teknik yang dimiliki sehingga dapat bersaing baik secara produk maupun harga; memberikan pelayanan all out sebagai salah satu cara untuk memberikan kepuasan pelanggan, sehingga dapat unggul; mematenkan produk agar memperoleh nilai ekonomi yang lebih besar; 


\section{sosio e-kons}

Volume 11, No. 1, April 2019, pp. 1-15

e-ISSN: $2502-5449$

p-ISSN: 2085-2266

DOI : 10.30998/sosioekons.v11i1.3068

memasarkan produk melalui komunitas/ kumpulan organisasi, sehingga mudah dikenali oleh anggota/ komunitas tersebut; dan menawarkan produk melalui public figure, dan lain-lain.

Keunggulan bersaing menurut Wilantara dan Susilawati (2016: 274) merupakan hasil dari implementasi strategi yang memanfaatkan berbagai sumber daya yang dimiliki perusahaan. Modal intelektual, khususnya kreativitas merupakan sumber keunggulan bersaing. Kontek tersebut, keahlian unik perusahaan menempatkan pegawai sebagai bagian penting dalam mencapai keunggulan bersaing. Hal penting yang perlu diperhatikan dalam keunggulan bersaing adalah membangun keunggulan relatif, dimana keunggulan relatif dibangun melalui keunggulan produk inti dan keunggulan pada kemampuan kinerja total.

Edgar P Hibbert (Burtonshaw, 2011: 186), dalam menentukan strategi dan pengembangan produk menggunakan pendekatan manajemen desain. Manajemen desain membagi 3 konsep dalam menentukan strategi produk, yaitu pertama, desain industri, terdiri dari pengetahuan estetis, latar belakang sosial dan budaya, hubungan lingkungan, persyaratan egronomis, wawasan aspek pemasaran dan produksi serta tren visual. Kedua, pemasaran, terdiri dari pamahaman riset pasar, analisis pasar, ekonomi, sistem distribusi dan promosi. Ketiga, produksi, menguraikan tentang riset teknis, analisis teknis, target ekonomis, metode produksi dan riset ergonomis.

Strategi produk mengkombinasikan jenis-jenis desain, yaitu desain kekhasan, desain produksi, desain fungsi, desain daya tarik /penampilan estetis dan desain distribusi. Desain kekhasan, yaitu berkaitan dengan pengembangan desain inovasi dengan tanpa teknologi, desain produksi, yaitu memastikan bahwa bagian komponen dibuat dengan mudah dan ekonomis dalam proses produksi, desain fungsi, yaitu menunjukkan kualitas dan reliabilitas, bahwa produk harus memuaskan pelanggan sebagai fungsi utama produk, desain daya tarik/penampilan entitas, yaitu berkaitan dengan daya tarik ekplisit untuk menarik pelanggan serta desain distribusi, yaitu untuk memfasilitasi pengemasan yang mudah dengan biaya rendah, pengurangan ruang penanganan dan penyimpanan serta penyampaian produk ke konsumen (Burtonshaw, 2011: 186).

Michael P Porter (Wilantara dan Susilawati, 2016: 275), berpendapat bahwa perusahaan yang memiliki keunggulan kompetitif senantiasa memiliki kemampuan dalam memahami perubahan pasar dan mampu memilih strategi pemasaran yang efektif dengan menetapkan 3 (tiga) kategori, yaitu cost leadership, differentiation dan focus. Strategi biaya rendah menekankan pada upaya memproduksi produk standar dengan biaya per unit yang sangat rendah. Strategi defferentiation adalah strategi untuk mendorong perusahaan sanggup menentukan dan menemukan keuanikan tersendiri dalam pasar sasarannya. Strategi focus adalah membangun keunggulan bersaing dalam satu segmen yang lebih sempit.

Desa Kebonharjo, Kecamatan Samigaluh, Kabupaten Kulonprogo merupakan daerah dataran tinggi yang terkenal dengan sebutan Pegunungan Menoreh. Di daerah tersebut terdapat pelaku usaha kecil sebagai upaya memenuhi kebutuhan ekonomi, seperti pembibitan susu kambing etawa, pengolahan susu kambing etawa, pengrajin gula aren, dan lain-lain. Keberadaan pelaku usaha kecil tersebut menjadi salah satu potensi desa dalam mengembangkan perekonomiannya terutama pada sektor usaha kreatif, peternakan, pertanian dan perkebunan. Desa Kebonharjo juga memiliki daya tarik alam sebagai magnet destinasi pariwisata yang cukup potensial dengan dukungan keindahan alam hayati. 
Inovasi produk menjadi salah satu strategi agar keberadaan suatu usaha memiliki dasar yang cukup untuk mengoptimalkan potensi daya saing. Selain itu, pengembangan inovasi produk yang dilakukan secara terencana dan terprogram diharapkan dapat meningkatkan nilai ekonomis untuk mensejahterakan pelaku usaha. Sebagai sasaran jangka panjang, keberhasilan kegiatan ekonomi di daerah tersebut mampu membawa Desa Kebonharjo menjadi salah satu desa yang memiliki produk khas daerah atau Produk Unggulan Daerah (PUD) yang dikenal masyarakat yang lebih luas, baik regional, nasional maupun global.

Penelitian ini bertujuan untuk mengetahui strategi inovasi produk yang telah dijalankan pada usaha kecil pengrajin gula kelapa dan peternak susu kambing etawa di Desa Kebonharjo, Kecamatan Samigaluh, Kabupaten Kulonprogo serta mengetahui hambatan-hambatan yang dihadapinya.

\section{METODE}

Metode yang digunakan dalam penelitian ini adalah metode penelitian kualitatif dengan pendekatan deskriptif sequential explanatory. Data yang digunakan dalam penelitian ini adalah data primer dan data sekunder yang diperoleh dari narasumber atau responden yang dianggap dapat mewakili dan memahami secara lebih mendalam berkaitan dengan informasi, data, hambatan dan permasalahan yang dihadapi oleh UKM di Desa Kebonharjo, Samigaluh, Kulonprogo. Informan dalam penelitian ini Kepala Desa Kebonharjo dan perangkat desa, penggiat atau pemerhati usaha di Desa Kebonharjo, pengurus kelompok tani serta pengrajin gula kelapa dan peternak susu kambing etawa di wilayah tersebut. Pengumpulan data dilakukan dengan observasi lapangan, wawancara, dokumentasi, dan pengisian lembar angket.

Indikator yang digunakan untuk mengukur tingkat inovasi Produk adalah desain kekhasan, desain produksi, desain fungsi, desain daya tarik/penampilan entitas dan desain distribusi. Tingkat inovasi diukur melalui pendekatan angka indeks. Angka indeks dapat dikembangkan untuk mendapatkan gambaran mengenai derajat atas variabel yang diteliti, selanjutnya menggunakan kriteria tiga kotak (three box method) untuk menentukan kategori (Ferdinand, 2006:291). Indek inovasi produk pada pengolah susu kambing etawa dikelompokkan interval dengan three box method sebagai berikut :

Tabel 1

Three Box Method Tingkat Inovasi

\begin{tabular}{cll}
\hline \multicolumn{1}{c}{ Produk } & \multicolumn{1}{c}{ Range Indeks } & \multicolumn{1}{c}{ Kategori } \\
\hline \multirow{3}{*}{ Gula Aren } & Antara 10,80 sampai dengan 25,19 & Rendah \\
& Antara 25,20 sampai dengan 39,59 & Sedang \\
& Antara 39,60 sampai dengan 54 & Tinggi \\
\hline \multirow{3}{*}{ Susu Kambing Etawa } & Antara 4,20 sampai dengan 9,79 & Rendah \\
& Antara 9,80 sampai dengan 15,39 & Sedang \\
& Antara 15.40 sampai dengan 21 & Tinggi \\
\hline
\end{tabular}

Sumber : dikembangan peneliti, 2018

Range indeks inovasi pada pengrajin gula aren dimulai dari angka 10,80 sebagai batas bawah dengan asumsi seluruh responden yang berjumlah 54 menjawab dengan skor 1, sampai dengan 54 sebagai batas atas dengan asumsi seluruh responden menjawab dengan skor 5 . 


\section{sosio e-kons}

Volume 11, No. 1, April 2019, pp. 1-15

e-ISSN: $2502-5449$

p-ISSN: 2085-2266

DOI : 10.30998/sosioekons.v11i1.3068

sehingga didapatkan rentang 43,20 (54 - 10,80). Dalam penelitian ini digunakan kriteria 3 kotak (three box method), kemudian untuk mendapatkan interval pada setiap kotak maka rentang 43,20 dibagi 3 sehingga menghasilkan interval 14,40.

Range indeks inovasi pada pengolah susu kambing etawa dimulai dari angka 4,20 sebagai batas bawah dengan asumsi seluruh responden yang berjumlah 21 menjawab dengan skor 1, sampai dengan 21 sebagai batas atas dengan asumsi seluruh responden menjawab dengan skor 5. sehingga didapatkan rentang $16,80(21-4,20)$. Dalam penelitian ini digunakan kriteria 3 kotak (three box method), kemudian untuk mendapatkan interval pada setiap kotak maka rentang 16,80 dibagi 3 sehingga menghasilkan interval 5,60.

\section{HASIL DAN PEMBAHASAN}

Desa Kebonharjo merupakan salah satu desa yang berada di wilayah Kabupaten Kulonprogo, terletak di sebelah Barat Daya Kota Yogyakarta. Desa tersebut merupakan perbatasan antara Kabupaten Kulonprogo dengan Kota Magelang. Desa Kebonharjo mempunyai 10 (sepuluh) dusun, yang masyarakatnya sebagian besar adalah petani. Desa ini telah melaksanakan administrasi kepemerintahan dengan baik terbukti bahwa selain dapat diakses secara transparan bagi masyarakat juga tercatat dengan jelas sumber dana maupun bentuk-bentuk pengeluarannya. Dari laporan desa 2017 total pendapatan Desa Kebonharjo, Samigaluh, Kulonprogo sebesar Rp. 1.690.387.081,- yang dialokasikan untuk pembangunan desa sebesar Rp. 1.034.547.777,- penyelenggaraan pemerintah desa Rp. 553.101.398,-, pembinaan kemasyarakatan sebesar Rp. 73.531.050,- serta pemberdayaan masyarakat sebesar Rp. 29.206.856,-.

Desa Kebonharjo memiliki potensi besar untuk menjadi salah satu desa yang melahirkan UKM dengan ciri khas kearifan lokal, yaitu produk susu kambing etawa dan gula aren. Potensi ini harus terus dioptimalkan peluangnya sehingga benar-benar menjadi produk unggulan Desa Kebonharjo sebagai alat daya saing daerah. Pemerintah Desa Kebonharjo sampai dengan saat ini terus berupaya untuk melakukan pemberdayaan masyarakat melalui usaha-usaha kecil dan menengah, baik melalui program kemitraan, melaksanakan pameran produk UKM, keterbukaan terhadap program Perguruan Tinggi, misalnya, menerima mahasiswa untuk Kuliah Kerja Nyata (KKN) dan sebagainya. Upaya pemberdayaan masyarakat juga dapat terlihat dari besaran anggaran yang dialokasikan, seperti tersebut di atas.

Berkaitan dengan kemitraan, saat ini pelaku usaha kecil menengah di Desa Kebonharjo hampir $70 \%$ telah melakukan kerjasama, walaupun masih terbatas pada wilayah setempat. Kepala Desa Kebonharjo berpendapat bahwa melalui pengembangan kemitraan atau programprogram yang dijalankan Pemerintah Desa Kebonharjo saat ini dapat meningkatkan motivasi dan inisiatif pengembangan usaha UKM. Tantangan yang paling sulit adalah membangun motivasi pelaku usaha untuk lebih fokus menjadi wirausaha sejati. Di sisi lain, para pengrajin gula aren dan peternak susu kambing etawa menghadapi minimnya modal untuk mengembangkan usahanya sehingga inovasi produk belum dapat mereka lakukan dengan baik.

Inovasi produk menjadi pembahasan fokus dalam penelitian ini. Melalui observasi lapangan langsung, wawancara serta kuesioner sebagai dukungan data untuk mengukur tingkat inovasi produk, diperoleh data yang menggambarkan inovasi produk telah dilakukan oleh pengrajin dan petani. Selanjutnya adalah memberikan rujukan serta implementasi strategi yang 
Volume 11, No. 1, April 2019, pp. 1-15

e-ISSN: 2502-5449

p-ISSN: 2085-2266

DOI : 10.30998/sosioekons.v11i1.3068

dapat diterapkan untuk meningkatkan daya saing daerah atas produk susu kambing etawa dan gula aren.

Asumsi awal penelitian ini adalah bahwa inovasi produk merupakan faktor yang dapat mempengaruhi daya saing UKM maupun keberadaannya sebagai kegiatan ekonomi rakyat sebagai upaya memenuhi kebutuhan dan kualitas kehidupan ekonomi masyarakat. Pada beberapa penelitian terdahulu, yaitu Elfahmi dan Jatmiko (2017) telah membuktikan bahwa inovasi berpengaruh terhadap daya saing produk, inovasi produk berpengaruh terhadap UKM naik kelas, daya saing produk berpengaruh terhadap UKM naik kelas serta inovasi produk berpengaruh terhadap UKM naik kelas melalui daya saing produk. Penelitian jenis kuantitaif lainnya oleh Hadiyati (2011) membuktikan bahwa kreativitas dan inovasi berpengaruh secara simultan terhadap kewirausahaan, inovasi memiliki pengaruh lebih dominan terhadap kewirausahaan. Inovasi dan kreativitas tidak hanya berpengaruh terhadap daya saing atau keberhasilan kewirausaan oleh UKM, tetapi juga berpengaruh terhadap bisnis yang dijalankan oleh perusahaan besar. Dama dan Ogi (2018) membuktikan bahwa inovasi berpengaruh terhadap kinerja karyawan pada PT Bank Mandiri (persero) Manado dan kreativitas berpengaruh terhadap kinerja karyawan PT Bank Mandiri (persero) Manado.

\section{Tingkat Inovasi Produk}

Keberadaan usaha produksi susu kambing etawa bagi sebagian masyarakat Kebonharjo bukan sebagai mata pencaharian utama. Mata pencaharian utama mereka adalah sebagai petani atau berkebun. Dari observasi yang dilakukan pada 21 sampel peternak susu kambing etawa yang aktif di Desa Kebonharjo, Samigaluh, Kulonprogo dapat menggambarkan tingkat inovasi dan pengembangan produk yang telah dilakukan. Tingkat inovasi produk dalam penelitian ini diukur dengan pendekatan angka indeks pada indikator desain kekhasan, desain produksi, desain fungsi, desain daya tarik kemasan dan desain distribusi.

Hasil analisis tingkat inovasi pengembangan pada produk susu kambing etawa pada indikator desain kekhasan diilustrasikan pada tabel 1 berikut ini.

Tabel 2

Indeks Inovasi Produk Susu Kambing Etawa Desa Kebonharjo

\begin{tabular}{|c|c|c|c|c|}
\hline No & Indikator & Sub indikator & Indeks & Kategori \\
\hline \multirow{5}{*}{1} & \multirow{5}{*}{$\begin{array}{l}\text { Desain } \\
\text { Kekhasan }\end{array}$} & Penggunaan alat Modern dalam proses produksi (DK1) & 12,80 & sedang \\
\hline & & Penggunaan alat modern pada kemasan (DK2) & 13,20 & sedang \\
\hline & & Upaya mencari cara baru dalam produksi (DK3) & 14,00 & sedang \\
\hline & & Ciri kahs produk antar produk dalam satu daerah (DK4) & 9,60 & rendah \\
\hline & & Ciri Khas produk antar daerah / pesaing (DK5) & 12,80 & rendah \\
\hline \multirow{5}{*}{2} & \multirow{5}{*}{$\begin{array}{l}\text { Desain } \\
\text { Produksi }\end{array}$} & Perhatian terhadap biaya produksi (DP1) & 17,60 & tinggi \\
\hline & & Perhatian terhadap proses produksi yang berurutan (DP2) & 16,60 & tinggi \\
\hline & & Kecepatan produksi (DP3) & 12,00 & sedang \\
\hline & & Perhatian terhadap resiko produksi (DP4) & 16,00 & tinggi \\
\hline & & Ketelitian (DP5) & 17,00 & tinggi \\
\hline \multirow{5}{*}{3} & \multirow{5}{*}{$\begin{array}{l}\text { Desain } \\
\text { Fungsi }\end{array}$} & Daya tahan produk (DF1) & 11,00 & sedang \\
\hline & & Kesesuaian dengankeinginan pelanggan (DF2) & 10,60 & sedang \\
\hline & & Aman dikonsumsi (DF3) & 17,60 & tinggi \\
\hline & & Kualitas manfaat produk (DF4) & 15,40 & tinggi \\
\hline & & Komplain pelanggan (DF5) & 15,20 & sedang \\
\hline 4 & Desain & Daya tarik kemasan secara umum (DT1) & 11,60 & sedang \\
\hline
\end{tabular}


Volume 11, No. 1, April 2019, pp. 1-15

e-ISSN: 2502-5449

p-ISSN: 2085-2266

DOI : 10.30998/sosioekons.v11i1.3068

\begin{tabular}{llrl} 
Daya & Daya tarik warna kemasan (DT2) & 15,40 & tinggi \\
Tarik & Kebersihan dan kerapihan (DT3) & 12,60 & sedang \\
Kemasan & Ukuran Ideal kemasan (DT4) & 16,00 & tinggi \\
& keunikan bentuk kemasan (DT5) & 12,40 & sedang \\
\hline \multirow{3}{*}{ Desain } & Distribusi merata (DD1) & 9,00 & rendah \\
& Perhatian terhadap penyimpanan (DD2) & 9,80 & rendah \\
Distribusi & Kemudahan pengangkutan (DD3) & 17,20 & tinggi \\
& Ukuran produk saat proses distribusi (DD4) & 16,80 & tinggi \\
& Jaringan kemitraan (DD5) & 15,40 & tinggi \\
\hline
\end{tabular}

Sumber : Data primer diolah, 2018

Berdasarkan hasil di atas, dapat ditentukan rata-rata indeks pada setiap indikator inovasi bahwa tingkat inovasi yang diukur melalui indikator desain kekhasan rata-rata indeks sebesar 12,48 dengan kategori sedang, desain produksi 15,84 pada kategori tinggi, desain fungsi 13,96 pada kategori sedang dan desain distribusi sebesar 13,64 berada pada kategori sedang. Dari 5 (lima) indikator yang digunakan dalam penelitian ini menunjukkan bahwa terdapat satu indikator berada pada kriteria tinggi dalam inovasi produk susu kambing etawa yaitu indikator desain produksi, sedangkan untuk 4 (empat) indikator lainnya berada pada kategori sedang.Secara keseluruhan dapat disimpulkan bahwa tingkat inovasi pengembangan pada produk susu kambing etawa yang di produksi oleh pengusaha kecil di Desa Kebonharjo berada pada kategori sedang dengan indeks rat-rata sebesar 14,02.

Seperti halnya dengan usaha produksi susu kambing etawa, usaha membuat gula aren oleh pelaku usaha di Desa Kebonharjo tidak dijadikan sebagai mata pencaharian utama. Dari observasi yang dilakukan pada 54 sampel pengrajin gula aren yang aktif di Desa Kebonharjo, Samigaluh, Kulonprogo dapat digambarkan tingkat inovasi dan pengembangan produk yang telah dilakukan. Melalui pendekatan dan indikator yang sama, seperti pada pengukuran tingkat inovasi produk susu kambing etawa, berikut ini adalah tabel terperinci yang menggambarkan tingkat inovasi produk pengrajin gula aren di Desa Kebonharjo.

Tabel 3

Indeks Inovasi Produk Gula Aren Desa Kebonharjo

\begin{tabular}{|c|c|c|c|c|}
\hline No & Indikator & Sub indikator & Indeks & Kategori \\
\hline \multirow{5}{*}{1} & \multirow{5}{*}{$\begin{array}{l}\text { Desain } \\
\text { Kekhasan }\end{array}$} & Penggunaan Alat Modern dalam proses produksi (DK1) & 13,80 & rendah \\
\hline & & Penggunaan alat modern pada kemasan (DK2) & 12,00 & rendah \\
\hline & & Upaya mencari cara baru dalam produksi (DK3) & 15,40 & rendah \\
\hline & & Ciri kahs produk antar produk dalam satu daerah (DK4) & 26,60 & sedang \\
\hline & & Ciri Khas produk antar daerah / pesaing (DK5) & 21,00 & rendah \\
\hline \multirow{5}{*}{2} & \multirow{5}{*}{$\begin{array}{l}\text { Desain } \\
\text { Produksi }\end{array}$} & Perhatian terhadap biaya produksi (DP1) & 44,40 & tinggi \\
\hline & & Perhatian terhadap proses produksi yang berurutan (DP2) & 47,80 & tinggi \\
\hline & & Kecepatan produksi (DP3) & 21,20 & rendah \\
\hline & & Perhatian terhadap resiko produksi (DP4) & 45,60 & tinggi \\
\hline & & Ketelitian (DP5) & 47,60 & tinggi \\
\hline \multirow{5}{*}{3} & \multirow{5}{*}{$\begin{array}{l}\text { Desain } \\
\text { Fungsi }\end{array}$} & Daya tahan produk (DF1) & 43,40 & tinggi \\
\hline & & Kesesuaian dengan keinginan pelanggan (DF2) & 33,60 & sedang \\
\hline & & Aman dikonsumsi (DF3) & 49,40 & tinggi \\
\hline & & Kualitas manfaat produk (DF4) & 42,40 & tinggi \\
\hline & & Komplain pelanggan (DF5) & 45,00 & tinggi \\
\hline 4 & Desain & Daya tarik kemasan secara umum (DT1) & 29,00 & rendah \\
\hline
\end{tabular}


Volume 11, No. 1, April 2019, pp. 1-15

e-ISSN: 2502-5449

p-ISSN: 2085-2266

DOI : 10.30998/sosioekons.v11i1.3068

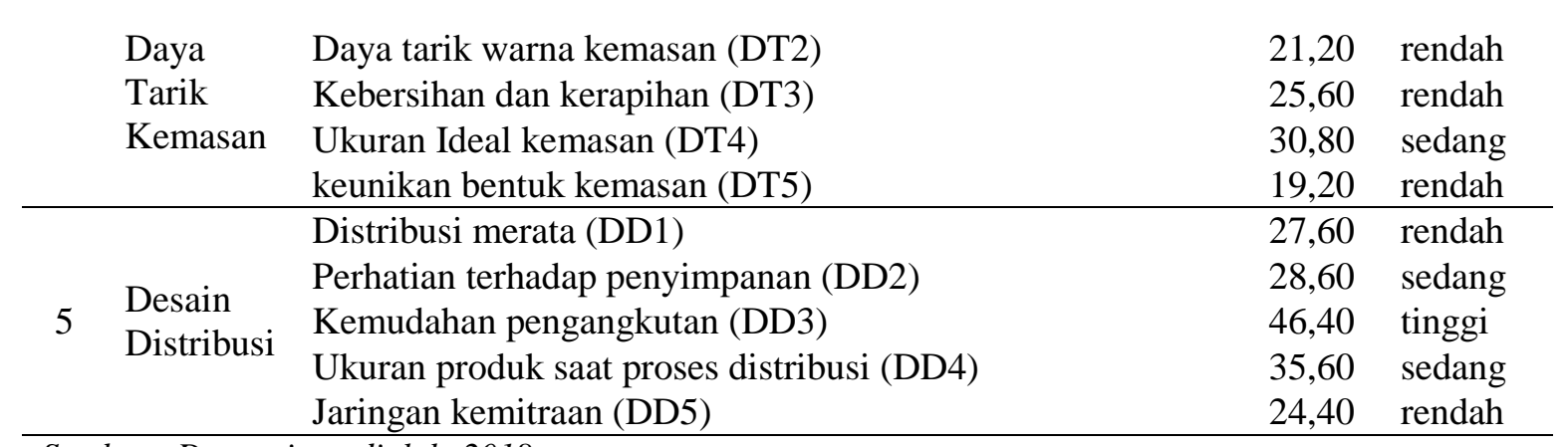

Sumber : Data primer diolah, 2018

Berdasarkan hasil di atas, dapat ditentukan rata-rata indeks pada setiap indikator inovasi bahwa tingkat inovasi yang diukur melalui indikator desain kekhasan rata-rata indeks sebesar 17,76 dengan kategori rendah, desain produksi 41,32 pada kategori tinggi, desain fungsi 42,76 pada kategori tinggi, desain daya tarik kemasan 25,16 pada kategori rendah dan desain distribusi sebesar 30,52 berada pada kategori sedang.

Dari 5 (lima) indikator yang digunakan dalam penelitian ini menunjukkan bahwa terdapat 2 (dua) indikator inovasi produk gula aren berada pada kriteria tinggi, yaitu indikator desain produksi dan desain fungsi. Indikator desain distribusi adalah satu-satunya yang menunjukkan pada kategori sedang, sedangkan 2 (dua) indikator lainnya, yaitu desain daya tarik kekhasan dan desain data tarik kemasan berada pada kategori rendah. Secara keseluruhan indek inovasi produk gula aren berada pada kategori sedang dengan skor indeks sebesar 31,50.

Baik usaha peternak susu kambing etawa maupun pengrajin gula aren di Desa Kebonharjo, Samigaluh, Kulonprogo memiliki tingkat inovasi pada tingkat sedang. Namun begitu dalam beberapa sub indikator terdapat kategori tinggi dan atau sedang pada batas atas atau mendekati tinggi. Berdasarkan tingkat inovasi yang berada pada kategori sedang tersebut menunjukkan bahwa usaha pengrajin gula aren maupun peternak susu kambing etawa masih perlu dioptimalkan.

\section{Hambatan dan Strategi}

Usaha Kecil dan Menengah (UKM) di Indonesia cenderung menghadapi berbagai kendala atau hambatan dalam usahanya meskipun jumlah pelakunya meningkat setiap tahunnya namun perkembangannya tidak seimbang dengan pertumbuhannya. Seperti yang diuraikan oleh Sasono (2008:76), bahwa tidak berkembangnya usaha kecil akibat adanya nilai-nilai atau tradisi suatu kelompok masyarakat yang memang tidak mampu mendinamisasi keadaan masyarakatnya, Hal tersebut dilihat dari sisi kultural, sedangkan dari sisi struktural, sulit berkembangnya usaha kecil akibat adanya struktur sosial ekonomi masyarakat yang timpang sehingga mengakibatkan sekelompok masyarakat tertentu tidak mungkin bisa mengembangkan dirinya. Pernyataan ini dialami oleh peternak susu kambing etawa dan pengrajin gula aren di Desa Kebonharjo, Samigaluh, Kulonprogo.

Peternak susu kambing etawa belum secara optimal mengembangkan produk susu yang diproduksi. Akan tetapi, dalam beberapa peternak sudah memproduksi susu kambing yang dikembangkan menjadi produk varian lain, yaitu ice cream susu kambing etawa. Pengembangan produk ini merupakan hasil sentuhan pembinaan dan pelatihan yang dilakukan penggiat Usaha Kecil di Desa Kebonharjo yang bekerjasama dengan Pemerintah Desa 


\section{sosio e-kons}

Volume 11, No. 1, April 2019, pp. 1-15

e-ISSN: 2502-5449

p-ISSN: 2085-2266

DOI : 10.30998/sosioekons.v11i1.3068

Kebonharjo. Pelatihan tersebut dilaksanakan pada tahun 2016 dan pada tahun yang sama produk ice cream telah diproduksi dan dipasarkan terbatas di desa tersebut.

Produk ice cream telah dikemas secara modern yang menyerupai produk-produk ice cream modern yang diproduksi oleh perusahaan-perusahaan ice cream di pasar. Hanya kemasan produk ice cream Kebonharjo belum memiliki ciri khas atau merk beserta sisi legalitasnya. Kemasan yang dibuat adalah kemasan umum yang dibeli dari produsen kemasan / toko di Kota Yogyakarta. Hal tersebut sangat memungkinkan kemasan ice cream susu kambing etawa Desa Kebonharjo sama persis dengan kemasan ice cream produksi wilayah lain karena kemasan ini dijual bebas.

Peternak susu kambing etawa belum dan enggan untuk memproduksi susu dalam varian susu bubuk. Menurut mereka, produk susu bubuk selain membutuhkan biaya atau alat yang relatif mahal, susu bubuk merupakan hasil reaksi beberapa zat kimia sehingga akan mengurangi gizi atau kualitas susu kambing etawa. Hal ini mengindikasikan bahwa peternak susu kambing etawa konsisten dalam menjaga kualitas susu kambing yang natural/murni. Kepala Desa Kebonharjo juga sepakat bahwa susu kambing etawa di daerahnya adalah susu yang alami yang belum tersentuh kimia yang dapat mengurangi kadar gizi. Menurut beliau bahwa varian yang muncul dalam bentuk ice cream merupakan upaya memotivasi agar para peternak susu kambing etawa memiliki kreativitas dalam mengembangkan usahanya. Selain itu, diharapkan dengan adanya varian tersebut masyarakat yang selama ini enggan mengkonsumsi susu kambing, memiliki ketertarikan untuk mengkonsumsi dengan harga terjangkau dan sehat. Selama ini produksi susu kambing etawa sebagian besar berbentuk cair alami dan kemudian didistribusikan ke produsen susu bubuk kemasan, salah satunya adalah produsen yang berada di kawasan Kaligesing, Purworejo, Jawa Tengah sebagai pembeli utama produk mereka.

Peternak susu kambing etawa belum memiliki mitra distribusi untuk menyalurkan produknya ke berbagai wilayah. Hal ini juga dikarenakan produk mereka yang relatif homogen (susu cair), kondisi geografis yang sulit terjangkau menyebabkan sulitnya akses distribusi, dukungan akses pemasaran yang masih kurang serta konsistensi peternak dalam memproduksi susu kambing etawa. Sebagian para peternak susu kambing etawa, memenuhi kebutuhan ekonomi dengan bersandar pada keadaan alam, misalnya saat musim cengkeh mereka jualan atau mengejar produksi cengkeh, saat musim padi mereka memproduksi padi dan sebagainya. Usaha susu kambing masih belum menjadi fokus utama dalam kegiatan usaha mereka yang berdampak pada volume produksi belum dapat secara kontinyu serta dalam jumlah yang relatif rendah.

Hal yang sama juga dialami oleh pengrajin gula aren. Mereka belum mampu menciptakan desain kekhasan, ini terlihat dari rendahnya skor indeks pada hasil yang telah diuraikan bagian sebelumnya. Dalam sub indikator desain kekhasan, sebagian besar dari pengrajin masih menggunakan cara produksi tradisional bahkan relatif belum tersentuh penggunaan teknologi. Pengrajin masih menggunakan kayu bakar dalam memproses (memasak) nira aren, menggunakan bambu untuk mendapatkan nira sampai pada upaya merangsang pohon aren agar menjadi subur atau memungkinkan pohon aren dapat dipanen sesering mungkin.

Pada sub indikator lainnnya, dalam pengemasan gula yang telah jadi, pengrajin tetap menggunakan kemasan klasik/ tradisional, yaitu daun pisang, daun aren yang sudah dikeringkan bahkan menggunakan plastik bening bekas atau bahan lainnya yang dianggap 


\section{sosio e-kons}

Volume 11, No. 1, April 2019, pp. 1-15

e-ISSN: $2502-5449$

p-ISSN: 2085-2266

DOI : 10.30998/sosioekons.v11i1.3068

dapat untuk membungkus produk. Tidak ada merk menempel pada gula aren yang mereka produksi. Keadaan ini tentu berdampak pada tidak ada yang dapat membedakan antara gula aren produksi pengrajin A dengan produksi pengrajin B atau gula aren Kebonharjo dengan gula aren lain, misalnya dari daerah Magelang. Uniknya dari hasil wawancara yang dilakukan, sebagaian besar pengrajin gula aren mengetahui dan dapat membedakan produk yang dia produksi dengan produk gula aren yang diproduksi oleh tetangganya atau pengajin lainnya.

Pengrajin gula aren di desa Kebonharjo juga belum atau tidak memiliki keinginan untuk mencoba mendesain tampilan gula aren dari bentuk setengah lingkaran ke bentuk yang lainnya. Bagi mereka dengan bentuk gula yang telah dibuat sudah bisa dijual ke pasar setempat atau laku dengan cepat. Pengrajn gula aren belum bisa memenuhi permintaan secara kontinyu kepada pelanggannya, apalagi distribusi ke luar daerah karena minimnya produksi dan sulitnya mendapatkan nira yang tergantung dari alam.

Hal yang sangat patut dibanggakan dari pengrajin gula aren adalah ketelitian dan menjaga kualitas hasil produksi. Sebagian besar dari pengrajin gula aren menguasai langkah-langkah membuat atau menghasilkan gula aren yang berkualitas, sehingga dapat dipastikan bahwa produksi gula aren yang berasal dari Desa Kebonharjo memiliki fungsi dan kualitas yang baik, terjaga naturalnya atau tanpa bahan pengawet. Dari pelanggan-pelanggan mereka, mayoritas pengajin gula aren mengatakan bahwa tidak pernah menemui komplain dari pembelinya, kecuali komplain masalah ketersediaan produk yang minim.

Dari uraian-uraian tersebut, dapat disimpulkan bahwa baik pengrajin gula aren maupun peternak susu kambing etawa menghadapi kendala inovasi, yaitu (1) tidak menjadikan usaha sebagai profesi atau pekerjaan tetap, (2) penjalankan usaha berdasarkan warisan turun temurun baik cara maupun pengembangannya. (3) lokasi geografis yang relatif sulit dijangkau oleh supplier atau mitra, (4) motivasi pengembangan usaha yang relatif kurang, (5) kapasitas produksi relatif tergantung dari ketersediaan sumber daya alami, (6) modal yang kurang untuk melakukan investasi inovasi, (7) akses pemasaran dan distribusi yang minim, (8) pola kegiatan ekonomi yang relatif substantif dan (9) keunggulan komparatif yang membuat masyarakat merasa nyaman.

Terlepas dari beberapa kendala tersebut, para pelaku usaha kecil menegah di Desa Kebonharjo memiliki beberapa keunggulan dalam kegiatan produksi gula aren dan susu kambing etawa, yaitu (1) produk yang dihasilkan memiliki fungsi yang utuh atau natural, (2) keteguhan dan kesabaran dalam menjalankan usaha, (3) solidaritas antar peternak atau pengrajin sangat kuat, (4) menjaga nilai-nilai produk kekhasan daerah, (5) kemampuan, ketelitian dan keuletan dalam menjalani usaha, (6) keterbukaan masyarakat terhadap pihak luar untuk memberikan penyuluhan atau pembinaan berkaitan dengan usahanya, (7) memiliki kesadaran penuh tentang inovasi produk dilaksanakan pada usahanya belum optimal dan(8) memiliki kemandirian yang baik dalam menjalankan usaha.

Adanya berbagai keterbatasan dan sisi positif yang dialami oleh pengusaha kecil di Desa Kebonharjo, Samigaluh, Kulonprogo menjadi pekerjaan rumah yang besar yaitu bagaimana untuk mengangkat UKM di Desa Kebonharjo Samigaluh Kulonprogo, khususnya produksi susu kambing etawa dan gula aren. Berkembangnya kebutuhan yang semakin komplek di masyarakat mendorong tumbuhnya berbagai aktifitas usaha dengan jangkauan yang makin luas. Sehingga terbentuk budaya dan kebiasaan usaha atau bisnis tertentu di kalangan masyarakat. Hal tersebut kemudian menjadi karakter yang relatif sederhana, yaitu memanfaatkan berbagai 


\section{sosio e-kons}

Volume 11, No. 1, April 2019, pp. 1-15

e-ISSN: $2502-5449$

p-ISSN: 2085-2266

DOI : 10.30998/sosioekons.v11i1.3068

sumber daya alam yang ada di lingkungannya, bekerja dengan kebiasaan/rutin, mentradisi yang pada akhirnya menjadi baku secara sendirinya. Maka tidak asing lagi bahwa UMKM di suatu wilayah tertentu masih melaksanakan usahanya dengan cara tradisional yang berkembang turun temurun.

Saat ini, persaingan usaha telah menjadi masalah bagaimana dapat bertahan dengan usahanya untuk mendapatkan margin atau penghasilan optimal dari usahanya. Persaingan kemudian makin kompleks saat berkaitan dengan minimnya bahan baku, sumber daya pendukung, seperti pekerja, teknologi serta manajemen yang mendorong untuk menemukan metode yang lebih efisien dalam meningkatkan volume usahanya. Metode dan cara kerja yang disusun secara situasional menjadikan setiap fase perjalanan usaha dihadapkan pada kondisi, tantangan, kebutuhan yang berbeda, sehingga dalam konteks ini sudah seyogyanya usaha untuk mendukung pengembangan UMKM harus mampu menjawab kebutuhan dan tantangan yang dihadapi oleh pelaku usaha UMKM sesuai dengan tahapan pengembangan usaha.

UKM di daerah, khususnya di Desa Kebonharjo memiliki potensi yang baik untuk dapat mengangkat produk kearifan lokal, produk susu kambing etawa maupun gula aren masih relatif terbatas jumlahnya di pasar. Dibutuhkan strategi bersaing yang memperhatikan 2 (dua) hal pokok yaitu membangun keunggulan produk inti dan kemampuan membangun kinerja total atas produk tersebut. Inovasi produk menjadi satu hal penting pada konteks ini.Keunggulan produk inti mendasarkan pada pemahaman atas manfaat utama produk inti yang ditawarkan, keunggulan kinerja produk secara keseluruhan baik dari sudut pemasaran, layanan pasca jual, strategi harga maupun distribusi produk. UKM harus mampu melihat dan meningkatkan atau membuka peluang untuk meraih keunggulan yang berkelanjutan.

Michael E Porter (Wilantara dan Susilawati, 2016: 274), bahwa perusahaan yang memiliki keunggulan kompetitif senantiasa memiliki kemampuan dalam memahami perubahan struktur pasar dan mampu memilih strategi pemasaran yang efektif. Porter menetapkan strategi generik yang diklsifikasikan dalam 3 (tiga) kategori, yaitu cost leadership, diferentiation dan focus.

\begin{tabular}{c|c|}
\multicolumn{1}{c}{} & \multicolumn{1}{c}{$\begin{array}{l}\text { Uniqueness of service } \\
\text { perceived by the client }\end{array}$} \\
\cline { 2 - 3 } All sector & Low Cost \\
\cline { 2 - 3 } Segment & \multicolumn{2}{c}{ Focus } \\
\cline { 2 - 3 } & Cost leadership \\
\cline { 2 - 3 } $\begin{array}{c}\text { Gambar 1. Strategi Generik } \\
\text { Sumber :Michael E Porter (1997:35) }\end{array}$
\end{tabular}

Berdasarkan pada strategi generik Porter, UKM di desa Keboharjo menerapkan cost leadership telah dijalankan melalui pemahaman dan penekanan biaya yang serendah-rendahnya (ekonomis), mereka sadar bahwa memproduksi dengan biaya rendah dapat menentukan harga jual murah dan diterima pelanggan. Konsep cost leadership yang diterapkan saat ini hanya sebatas "irit" dan cenderung kurang memperhatikan tuntutan pasar, misalnya, desain daya tarik kemasan yang kurang. Hal ini terjadi karena baik pembuatan maupun pengemasan produk masih relatif menggunakan cara tradisional. Cost leadership pada dasarnya diposisikan Sebagai 


\section{sosio e-kons}

Volume 11, No. 1, April 2019, pp. 1-15

e-ISSN: 2502-5449

p-ISSN: 2085-2266

DOI : 10.30998/sosioekons.v11i1.3068

produk yang ditawarkan memiliki harga murah ketika perilaku konsumen tidak terlalu peduli terhadap merk, akan tetapi bukan berarti mengenyampingkan sisi kualitas dan tampilan yang membuat produk inti memiliki fitur atau daya tarik yang menggoda konsumen.

Pada strategi differentiation, peternak susu kambing etawa dan pengrajin gula aren belum memiliki atau menerapkan secara optimal. Seperti pada ulasan sebelumnya pada penelitian ini, produk masih bersifat tradisional dan cenderung subtantif. Produksi yang dilakukan relatif hanya terbatas pada pasar internal dan atau kebutuhan untuk dikonsumsi sendiri. Pembeli atau konsumen produk susu kambing etawa ataupun gula aren adalah konsumen yang sama. Sehingga konsep deferensiasi masih belum memberikan ciri khas khusus terhadap produkproduk sejenis. Meskipun demikian, menurut mereka, produk yang dibuat dapat dikenali dengan mudah oleh pembuatnya, tetapi tidak oleh sebagian pembeli. Hal ini memungkinkan bahwa produk susu kambing etawa dan gula aren UKM Kebonharjo sama persis atau tidak dapat dibedakan dari produk sejenis bagi konsumen potensial.

Keunikan produk UKM diharapkan mampu menciptakan keunggulan, misalnya, kemudahan penyimpanan, fleksibilitas, merek maupun fitur tambahan yang dapat merangsang persepsi konsumen untuk tertarik mengkonsumsi produk serta merekomendasikan kepada konsumen lainnya. Jika konsep deferensiasi diterapkan dengan baik, produk yang ditawarkan dapat menarik pembeli potensial yang tidak melihat harga sebagai faktor keputusan pembelian.

Strategi focus digunakan untuk membangun keunggulan bersaing dalam suatu segmen pasar yang lebih sempit. Dalam pelaksanaannya di UKM strategi ini diintegrasikan dengan salah satu segmen pasar khusus/khas dalam pasar tertentu. Peternak susu kambing etawa dan pengrajin gula aren memiliki pasar khusus dan sangat terbatas, yaitu konsumen internal daerah/pasar tradisional. Hasil produksi gula aren, misalnya, hanya terbatas ditawarkan atau bahkan habis ketika ditawarkan ke pasar tradisional. Volume penjualan yang terhambat pada sumber daya alam (pohon aren) membuat produksi mereka tidak bisa menjangkau pasar lebih luas.

Pada produk susu kambing etawa memiliki sedikit perbedaan konsumen, susu kambing etawa lebih memenuhi kebutuhan supplier yang mengemas atau menjadikan produk susu kambing etawa menjadi produk modern, bermerk, varian bubuk dan menjangkau pasar lebih luas. Produk susu kambing etawa dibeli oleh pembeli pasti sebagai pemasok produk susu etawa modern dan tanpa adanya perjanjian khusus kerjasama antara peternak dan distributor/supplier.

Jika focus diimplementasikan kepada pengusaha total dalam pengelolaan usaha, peternak susu kambing etawa dan pengrajin gula aren masih menjadikan usaha ini berada di antara sampingan dan pokok. Ketergantungan terhadap keberadaan sumber daya alam sebagai keunggulan komparatif menjadikan pola menjalankan usaha adalah melihat peluang terdekat, misalnya saat musim bercocok tanam padi mereka mengurangi fokus usaha susu kambing etawa, ketika alam berada pada musim panen cengkeh mereka lebih fokus pada memanen dan menjual cengkeh di pasar dari pada susu kambing etawa.

Dari banyak pengalaman wirausahawan yang dijalankan, tingkatan kemampuan wirausahawan lebih condong pada risk calculation taker atau berani mengambil risiko usaha dengan perhitungan aman. Tingkat kemampuan kewirausahaan dalam menghadapi rasa takutnya lebih tinggi dan memiliki keberanian untuk menanggung atau mengatasi risiko kegagalan. Berani 


\section{sosio e-kons}

Volume 11, No. 1, April 2019, pp. 1-15

e-ISSN: $2502-5449$

p-ISSN: 2085-2266

DOI : 10.30998/sosioekons.v11i1.3068

menghadapi rasa takutnya karena ia merasa mampu, memiliki pengetahuan dan pengalaman kerja yang sesuai dengan yang ia kerjakan dalam bisnisnya (Ardiansyah, 2018). UMKM harus didorong dan diarahkan memiliki strategi bisnis yang tepat, sehingga mampu keluar dari masalah struktural yang dihadapi dalam usahanya secara mandiri. Dorongan ini diharapkan memunculkan sikap proaktif, mampu menyusun rencana penyelesaian masalah dan melaksanakanya secara berkesinambungan tanpa meninggalkan karakter dan sejarah maupun kearifan lokal atau keunggulan kompetitif yang dimiliki. Mendorong UKM, baik oleh pemerintah, swasta, Lembaga Swadaya Masyarakat (LSM), organisasi atau perguruan tinggi maupun phak-pihak lain, harus bersifat edukatif atau mengedukasi, memfasilitasi serta mengadvokasi strategi bisnis yang layak diambil oleh para pelaku usaha UKM. Pelaku UKM pada dasarnya telah memiliki kesadaran tinggi terhadap perubahan serta memiliki integritas tinggi terhadap fungsi usahanya, sehingga pada akhirnya mereka sendiri yang akan mampu membuat usahanya bertahan, berkembang di tengah persaingan atau pemenuhan kebutuhan yang dinamis.

\section{SIMPULAN}

Berdasarkan hasil penelitian yang telah dilaksanakan terhadap pengusaha UKM peternak susu kambing etawa dan gula aren di Desa Kebonharjo, Samigaluh, Kulonprogo, peneliti mesimpulkan penelitian ini adalah :

1. Indeks inovasi produk UKM susu kambing etawa sebesar 13,14 dan gula aren sebesar 31,80 , sehingga tingkat inovasi pengembangan produk kedua jenis produk tersebut berada pada kategori sedang.

2. Pengusaha UKM susu kambing etawa dan gula aren menghadapi permasalahan nilai-nilai atau tradisi suatu kelompok masyarakat yang tidak mampu mendinamisasi keadaan masyarakatnya dan struktur sosial ekonomi masyarakat yang timpang sehingga mengakibatkan sekelompok masyarakat tertentu tidak mungkin bisa mengembangkan inovasi produk secara maksimal.

3. Dibutuhkan peran dari luar untuk mengembangkan dan meningkatkan daya saing UKM susu kambing etawa dan gula aren di Desa Kebonharjo, Samigaluh, Kulonprogo yaitu pemerintah pusat maupun daerah, perusahaan swasta melalui program corporate social responsibility, Lembaga Swadaya Masyarakat (LSM), Perguruan Tinggi melalui program penelitian dan pengabdian masyarakat maupun pihak-pihak yang memiliki kepedulian terhadap keberadaan UKM dan pertumbuhan ekonomi masyarakat, baik individu maupun organisasi secara terarah dan berkelanjutan

\section{DAFTAR RUJUKAN}

Ardiansyah, T. (2018). Perspektif Tingkat Kemampuan dan Transformasi Wirausahawan Merubah Risiko Menjadi Sukses Berwirausaha. Sosio e-kons, Vol. 10, (2), Agustus, pp. $165-178$.

Assauri, S. (2011). Strategic Management Subtainable Competitive Advantages. Jakarta : Lembaga Manajemen FEUI

Astamoen, M. (2008). Entrepreneurship, Dalam Perspektif Kondisi Bangsa Indonesia. Bandung: Alfabeta. 


\section{sosio e-kons}

Volume 11, No. 1, April 2019, pp. 1-15

e-ISSN: 2502-5449

p-ISSN: 2085-2266

DOI : 10.30998/sosioekons.v11i1.3068

Basrowi. (2014). Kewirausahaan Untuk Perguruan Tinggi. Jakarta : Ghalia Indah

Burtonshaw, A, S. (2011). Alat dan Teknik Analisis Manajemen. Jakarta : Indeks Jakarta

Dama, J ., Ogi \& Imelda W.J. 2018. Pengaruh Inovasi dan Kreativitas Terhadap Kinerja Karyawan pada PT. Bank Mandiri (Persero)Tbk, Manado, Jurnal EMBA Vol.6 (1) Januari 2018, hh. 41-50, diakses dari https://ejournal.unsrat.ac.id/index.php/emba/article/download/18759/18301

Drucker, P. (2006). Classic Drucker. Jakarta: PT. Bhuana Ilmu Populer.

Elfahmi, Suryono, H, \& Jatmika, D. (2017). Pengaruh Inovasi Terhadap UKM Naik Kelas Melalui Daya Saing Produk (Studi Indo Burger). Seminar Nasional Sistem Informasi 2017, 14 September 2017, Fakultas Teknologi Informasi, UNMER Malang. https://seminar.unmer.ac.id/index.php/senasif/2017/paper/view/19/24

Ferdinand, A. (2006). Metode Penelitian Manajemen. Semarang : Badan Penerbit Universitas Diponegoro

Hadiyati, E. (2011). Kreativitas dan Inovasi Berpengaruh Terhadap Kewirausahaan Usaha Kecil, Manado. Jurnal Manajemen dan Kewirausahaan Vol.13 No.1, https://doi.org/10.9744/jmk.13.1.8-16

Kementerian Usaha Kecil dan Menengah. (2008). Undang-Undang UKM,Undang-Undang Republik Indonesia Nomor 20 Tahun 2008 Tentang Usaha Mikro, Kecil, Dan Menengah. Yogyakarta: PustakaYustisia

Porter , E.M, alih Bahasa Agus, M. (1997). Strategi Bersaing:Teknik Menganalisis Industri dan Pesaing. Jakarta : Penerbit Erlangga

Rusdiana. (2014). Kewirausahaan, Teori dan Praktik. Bandung: CV Pustaka Setia.

Sasono, A. (2008). Rakyat Bangkit Bangun Martabat. Jakarta: Pustaka Alfabeta.

Wilantara, F., R dan Susilawati. (2016). Strategi dan Kebijakan Pengembangan UMKM. Bandung : Refika Aditama

Zimmerer, T., \& Scarborough, N. (2005). Pengantar Kewirausahaan dan Manajemen Bisnis Kecil. Jakarta: PT Indeks. 